The Studios after the Studios 
POSt 45 Florence Dore and Michael Szalay, Editors Post•45 Group, Editorial Committee 


\section{The Studios after the Studios}

Neoclassical Hollywood (1970-2010)

J. D. Connor 
Stanford University Press

Stanford, California

(C) 2015 by the Board of Trustees of the Leland Stanford Junior University. All rights reserved.

This book has been published with the assistance of the Frederick W. Hilles Publication Fund of Yale University.

\section{MAKE THE WEATHER}

Written by CHRIS BUTLER, WILLIAM FICCA, DANIEL KLAYMAN,

MARC WILLIAMS and TRACY WORMWORTH

(C) 1983 FUTURE FOSSIL MUSIC

All rights for FUTURE FOSSIL MUSIC

Controlled and Administered by SPIRIT ONE MUSIC (BMI)

International Copyright Secured.

All Rights Reserved. Used By Permission.

My Rights Versus Yours

Words and Music by Carl Allan Newman

Copyright (C) 2007 BMG Gold Songs

All Rights Administered by BMG Rights Management (US) LLC

All Rights Reserved. Used by Permission.

Reprinted by Permission of Hal Leonard Corporation.

No part of this book may be reproduced or transmitted in any form or by any means, electronic or mechanical, including photocopying and recording, or in any information storage or retrieval system without the prior written permission of Stanford University Press.

Printed in the United States of America on acid-free, archival-quality paper

Library of Congress Cataloging-in-Publication Data

Connor, J. D., author.

The studios after the studios : neoclassical Hollywood (1970-2010) / J.D. Connor.

$$
\text { pages } \mathrm{cm} \text {-- (Post 45) }
$$

Includes bibliographical references and index.

ISBN 978-0-8047-9077-2 (cloth : alk. paper)

1. Motion picture studios--California--Los Angeles--History. 2. Motion picture industry--

California--Los Angeles--History. 3. Motion pictures--California--Los Angeles--History.

4. Hollywood (Los Angeles, Calif.)--History. I. Title. II. Series: Post 45.

PN1993.5.U65C626 2015

$384^{\prime} \cdot 80979494^{--d c 23}$

$$
2014045954
$$

ISBN 978-0-8047-9474-9 (electronic)

Typeset by Bruce Lundquist in 10/15 Minion 